\title{
Music, Ritual and Community among Romania's Orthodox Pilgrimages
}

\author{
Mirel BăNiCÁ
}

More than 20 years after the fall of the Communist regime, we are witnessing the unprecedented development of religious pilgrimage in Romania, a country where, according to the latest census, $84 \%$ of the population self-identifies as Orthodox Christian. Apart from the pilgrimages to well-known destinations (Jerusalem, Rome, etc.) organized by the Romanian Patriarchy's Pilgrimage Bureau, a separate category is the improvised, hybrid pilgrimages, both religious and touristic, organized by individuals using hired minibuses. This paper offers an ethnographic description of a pilgrimage. The focus is on the relationship between music, ritual, the sacred space of the pilgrimage and the public space. Music is used as a barrier and immaterial border to the ritual space, while in its interior it is better suited for the emotional control and the proper management of pilgrims. The analysis of pilgrimages points to new forms of blending of music and ritual, outside established institutional frameworks, as well as to changing notions of pilgrimage, movement, religious practice and piety.

Keywords: Music, ritual, pilgrimage, Orthodox Church, Romania, Orthodox monasticism, sacred space, communitas

Pilgrimages all over the world are full of music and sounds. Romania's orthodox pilgrimages are no exception to the rule. Pilgrims sing while queuing. One chants pricesne at Prislop, Suceava or Nicula. Religious music CD sellers advertise their albums by having public auditions with the aid of improvised audio systems. Beggars too sing from time to time. They tell the suffering and the pain or they murmur subtly some sort of para-religious chants, as to provoke public charity. The Church and its servants do most of the singing and this "official" liturgical music is spreading from tens of speakers hanged above the waiting line and in the general pilgrimage perimeter. Why did I find it important to study the role music plays in a pilgrimage? For various reasons, which I'll try to organize by order of importance. From the point of view of the pilgrimage anthropology, the sound cannot be disregarded because it's an integral part of the orthodox "affective" experience, generating emotion and meaning among pilgrims. Music is an essential part

\footnotetext{
* Mirel Bănică, Researcher, Institute for the History of Religions, The Romanian Academy, Bucharest. Address: Calea 13 Septembrie nr.13, Casa Academiei, Institutul Istoria Religiilor, Bucuresti, sector 5; e-mail: mirel7@yahoo.com
}

RES 7 (3/2015), p. 460-465

DOI: $10.1515 /$ ress-2015-0034 
of all religions, representing the bond with the creation and maintaining that special feeling of "communion" (communitas), the very essence of a religious ritual of this sort. In Victor Turner's vision, communitas is actually an unmediated meeting between individuals with equal rights, happening during the ritual process. Those individuals mutually recognize the identity that was temporarily assumed during the ritual ${ }^{1}$.

Through studying various chants as the pricesne one can test the permanence of some forms of popular religion, as well as the continuity and the change within society. Finally, the most important aspect is the relationship between music, the sacred space of the pilgrimage and the public space. Music is used as a barrier and immaterial border to the ritual space, while in its interior it is better suited for the emotional control and the proper management of pilgrims.

The pricesne. In June 2013, the satirical magazine "Catavencii" published a caricature by Ion Barbu, depicting a massive bearded priest, with his head covering on (in Romanian - potcap) and a (suggested) pile of musical manuscripts under the arm. The priest is talking to a group of elderly ladies, with head kerchiefs knotted under their chins, listening very carefully and watching all his moves. The priest tells them, while checking his wrist watch: "Girls, Saturday for Vespers we throw a karaoke with pricesne". Setting aside the corrosive humor of the scene (Ion Barbu has a long series of similar press drawings dedicate to relics, pilgrimages, priests' habits - in short, a refined observer of the religious phenomenon), one can perceive the fact that the pricesne (from Slavic pricestanie - parts of the Holy Communion) are part of the musical identity of the pilgrims. They are sung mainly by elderly ladies, being a strong identity marker of the pilgrim in the public space as well as in the media.

What are the pricesne after all? In what context did I hear them while on fieldwork? A possible definition: the pricesne are para-liturgical chants, tacitly accepted by the Church, marking the "empty spaces" in the liturgy. The Romanian Language Dictionary (D.L.R.) states Priceasna: type of chant performed in orthodox churches at the liturgical service while the priest or an important believer partakes ${ }^{2}$. They are performed quite often during pilgrimages, especially in the Transylvanian area or in an area with a central-European influence (as is the case for Nicula or Suceava pilgrimage, for instance). I've heard pricesne in Bucharest as well, but it was rather an individual, isolat-

1 Victor Turner, The Ritual Process. Structure and Anti-Structure, Aldine Publishing, Chicago 1969, p. 23.

2 D.L.R. XII, Romanian Academy Publishing House, Bucharest 2010, p. 1389. 
ed gesture. For those who sing pricesne, the text has a higher importance than the music. At the great Nicula pilgrimage on August 15th, pilgrims exchange pricesne. In the opinion of Costin Moisil, ethnomusicologist and researcher at the Romanian Peasant Museum of Bucharest, the pricesne exchange would be one of the main characteristics of the Nicula pilgrimage. Usually, pilgrims carry simple notebooks with hand written pricesne, exchanging texts ${ }^{3}$. I myself received an A4 piece of paper with hand written pricesne dedicated to father Arsenie Boca, as some sort of reward for driving a group of pilgrims from Prislop monastery to the city of Hateg. Pricesne are from this point of view an identity and an orthodox intra-confessional identifier, but with a clear Uniate heredity.

Music is an effective instrument of building the pilgrim community as it touches the participants, managing to articulate it as a whole - the musical play of the church bells, for example. As noticed by the French anthropologist David Le Breton, "the emotion is not a substance, an entity that can be described, but rather an affective tonality which extends over the entire behavior, social types of knowledge which nurture affective states more or less obviously seen by members of the same group ${ }^{4}$. How else could such a large number of people spread around such a big surface be "tied together" more efficiently if not through music? Rouget Gilbert, another French anthropologist, noticed that music was never a "secondary ingredient" in human rituals. On the contrary, it is pure action, with the target of organizing and "managing" the affective life. Why is that? Because, unlike other ritual components, music does not require words in order to be effective ${ }^{5}$.

I believe the authorities organizing those pilgrimages have understood this from the very first moment when they put up the speakers on the electricity poles, airing the Mass and other recorded religious chants nonstop; the bonding and consolidating sound opposes the fluidity of the pilgrim masses, giving birth to new and more expressive ways of communitas, as the term is understood by Victor Turner in his theories dedicated to rituality ${ }^{6}$. Music unveils itself within the popular universe of "materialized sacred", together with the other senses any fundamental religious act uses: sight, touch, smell and

3 Costin Moisil, "Problems of Identity in the Orthodox Church Music in Transylvania", in: New Europe College Yearbook, Bucharest 2013, p. 34.

4 David Le Breton, Les Passions ordinaires. Anthropologie des émotions, Paris 1998, p. 171.

5 Gilbert Rouget, La musique et la transe. Esquise d'une theorie generale des relations de la musique et de la possesion, Paris 1990, p. 22.

6 Guy L. Beck, Sacred Sound. Experiencing Music in World Religion, Waterloo, Ontario 2006, p.6. 
taste. The hearing has the property of "entering the religious extraordinary and converting it into sensorial " food " for popular religions, giving birth in some cases to an internal culture of the pilgrimage" (or other rituals) which doesn't always coincide with that of the official Church?

British sociologist Tia de Nora states that background music one can hear continuously in the public space (shops, gyms, government institutions) is an effective ingredient in producing and installing a certain sensation of space-temporal "order" in the area in which it is played. It's the same thing for pilgrimages. Besides, the overwhelming majority of pilgrims I talked to regarding the "ambient" religious music were perceiving it as a means of focusing and an efficient tool for inducing subjective and profoundly cognitive states according to the image they were creating themselves of the pilgrimage, the "better place" by definition. Tia de Nora stresses the fact that music in public spaces is more than an "inhibitor" for certain stress and fatigue induced actions, being more of a "construction and body organization device which contributed to the autodidactic building process of the self" ${ }^{8}$. I had the opportunity to check the author's ideas on the fieldwork, talking to the guards. They have repeatedly stated that religious music calms the people, making their job much easier. Music is a true "ritual operative", taking part both in its construction and the symbolic delimitation of the space in which it takes place'.

Thus, religious music played during pilgrimages represents a controlling and emotional instrument for management of the masses. It remains to be seen to what extent the "sonorous space" designed by the totality of musical sources in a pilgrimage contributes to delimiting the space (the place) of the pilgrimage from the public space of the surrounding city. Firstly, one can notice that the music which is played in the pilgrims' area has the capability of serving "contextual directions", delimitating the space and warning pilgrims and passer-bys "Attention, you have reached a pilgrimage spot!" Even if the pilgrim cannot (yet) see the reliquary or the waiting line (specific marks of the process), he can already hear the music, establishing thus a physical and metaphysical relationship with the surroundings ${ }^{10}$.

\footnotetext{
7 Alphonse Dupront, Du Sacré. Croisades et pèlerinages. Images et langages, Paris 1987, p. 357.

8 Tia De Nora, "Quand la musique de fond entre en action”, in: Terrain-Revue d'ethnologie de l'Europe 39 (3/2001), p. 80.

9 Miriam Rovsing-Olsen, "Musique, anthropologie: la conjoction necessaire", in: L'Homme. Revue francaise d'anthropologie, 171-172, Paris 2004, p. 18.

10 Jeffers Engelhardt, "The Acoustic of Geopolitics of Orthodox Practices in the EstonianRussian Border Region”, in: Hann Chris, Goltz Hermann (ed.), Eastern Christians in Anthropological Perspective, Berkeley 2010, p. 120.
} 
For each and every pilgrimage it is difficult to establish a representative and spatially delimiting consensus, taking into account the high amount of representations and controversies. When it takes place in a totally desecrated space, as can happen in a city, the pilgrimage changes, for those not actively taking part in the ritual, into a symbol of the confrontation between religious thinking and a rational on ${ }^{11}$. In this case, music represents one of the elements explaining the serenity of a pilgrimage site, through its capacity of maintaining the "sacred charge", the specific spiritual tension. Music unifies, it creates a feeling of community, becoming a sort of shield against the surrounding urban aggression. One can wonder in this particular context if "music" cannot have the same status as the "sacred" in Durkenheimian sociology: ensign and limit of the group, each of its members experiencing part of the allegiance through ritual chants, religious hymns, etc ${ }^{12}$. I had the chance to check this information during fieldwork. The Iasi Roman Catholic cathedral is in the immediate vicinity of the great Orthodox pilgrimage in honor of Saint Parascheva (October $10^{\text {th }}-16^{\text {th }}$ ). The Catholics were maintaining and proclaiming their identity during those very special days through religious music as well. The speakers in the churchyard and on the church walls were constantly airing liturgical music of the Catholic confession.

What is the effect that music has on the pilgrim body and gesture? Between 1930-1940, with radio and audio technology development, in Christian European churches a whole change took place regarding the use of public address systems during the religious ceremonies. Eventually, religious music and the Mass being aired through electro-acoustic amplification means was accepted, the Church stating that the religious ceremony in itself holds the higher importance. The loudspeakers become thus a means of power, the Church's "official" music imposing over the improvised dialogue of the pilgrims or other sounds. Regarding the popular pilgrimages from Portugal (arrail) studied by Pierre Sanchis, not so different in morphology and manifestation of the popular religion from some of our festivities (Nicula monastery), the side effects of using speakers had, in time, unpredictable effects: the other "voices" of the pilgrimage ceased, the spontaneous rural choirs shut up, the specific Portuguese popular music and dances from the pilgrimage surroundings disappeared ${ }^{13}$. The speaker annihilates thus the popular spontaneity of

11 Frédéric Gugelot, "Les deux faces de Lourdes. Lourdes de Zola et Les foules de Lourdes de Huysmans", in: Archives de Sciences Sociales des Religions 151 (3/2010), EHESS, Paris, p. 215.

12 Olivier Roueff, "Musique et émotions", in: Terrain - Revue d'ethnologie de l'Europe 37 (1/2001), p. 9.

13 Pierre Sanchis, Arraial: la fête d'un peuple. Les pèlerinages populaires au Portugal, EHESS, Paris 1997 , p. 244-249. 
the pilgramages but disciplines on a global scale not only the pilgrimage, but also the physical body of the pilgrims - Tia de Nora talks about a "common choreography", the mechanics of the bodies brought under a well defined and persistent musical ambient. Music is linked with the natural energy, with the kinetics of the movement and so, the human bodies capable of acquiring certain musical parameters execute specific, common moves, the tempo and the musical style plays a decisive role in creating emotional states. Without wishing to give a definite answer on the interpreted style's influence, I cannot refrain from observing the enormous difference between the decisive psaltic music with "Byzantine warriors" accents of Tronos band of the Romanian Patriarchy, aired during the Saint Dumitru-The-New pilgrimage on October 27 th and the slow, soppy one sung by the protopsalter Petru Moise (accompanied by an electronic organ) one can hear around the Saint George-The-New church in December at Saint Nicholas' day.

There remains to be seen in the future, in a more detailed research, how the differences in nuance and style can influence the pilgrim gesture, contributing to the spiritual comfort and the creation of a specific community. 